\title{
SOME DATA ON THE NATURE OF SULFUR-CON- TAINING PEPTIDE-NUCLEOTIDE COMPOUNDS OBTAINED FROM CHLORELLA CELLS AT DIFFERENT DEVELOPMENTAL STAGES IN THEIR LIFE CYCLE
}

\author{
EIJI HASE, SAYOKO MIHARA and HIROSHI TAMIYA \\ The Institute of Applied Microbiology, University of Tokyo, and the \\ Tokugawa Institute for Biological Research, Tokyo \\ Received for publication, January 18,1960
}

It has been reported in our previous papers $(1,2,3)$ that a certain peptidenucleotide compound (or compounds) containing sulfur was extractable with cold acid (trichloroacetic acid (TCA) or perchloric acid (PCA)) from Chlorella and yeast cells. The major sulfur component contained in this complex was found to be cyst(e)ine. Experimental evidence (4) indicated that this complex compound(s) may bear some important part in the process of nucleic acid formation and nuclear division of algal cells. In view of these observations it seemed pertinent to obtain further insight into the chemical nature as well as the biochemical functions of this compound. The present paper concerns some of the properties of the compound as they manifested themselves in the patterns of electrophoregram. Considering its significance in relation to the process of ripening and sulfur metabolism of algal cells, comparison was made of the compound(s) isolated from cells of different stages of development as well as cells which had been grown in a sulfur-deficient medium.

\section{MATERIALS AND METHODS}

The organism used was Chlorella ellipsoidea. The algal cells at the stage of nuclear division were obtained using the technique of synchronous culture in an ${ }^{35} \mathrm{~S}$-containing medium which has been reported in our previous paper $(4,5)$. The sulfur-deficient cells were obtained by growing the " $\mathrm{D}_{\mathrm{a}}$ cells" synchronously in a sulfur-free medium $(4,6)$. These algal cells were extracted three times with cold $\left(0^{\circ}\right) 10 \%$ TCA or PCA. The TCA in the extracts was removed by washing with ether repeatedly. The solutions thus obtained were lyophilized and used for the electrophoretic experiments. The procedures used in the zone electrophoresis were, unless otherwise stated, the same as those reported in the previous paper (3). All the spectrophotometric measurements were performed using a Cary recording spectrophotometer Model 14 M-50. 


\section{RESULTS AND DISCUSSIONS}

(1) Electrophoretic patterns of the TCA-extracts obtained from normal cells at the stage of nuclear division

When " $\mathrm{D}_{\mathrm{a}}$-cells" (smaller and photosynthetically most active cells) are grown synchronously under provision of adequate quantities of light, $\mathrm{CO}_{2}$ and nutrients, they grow into larger cells which have been referred to as $\mathrm{L}_{1}$-cells. During the period of this transformation, a certain amount of nuclear substances is accumulated in algal cells, but the $\mathrm{L}_{1}$-cells are still unable to divide when incubated in the dark. When $\mathrm{L}_{1}$-cells are further grown under normal photoautotrophic conditions, they are transformed into $\mathrm{L}_{2^{-}}$and then into $\mathrm{L}_{3}$-cells, the latter being wholly capable of cell division

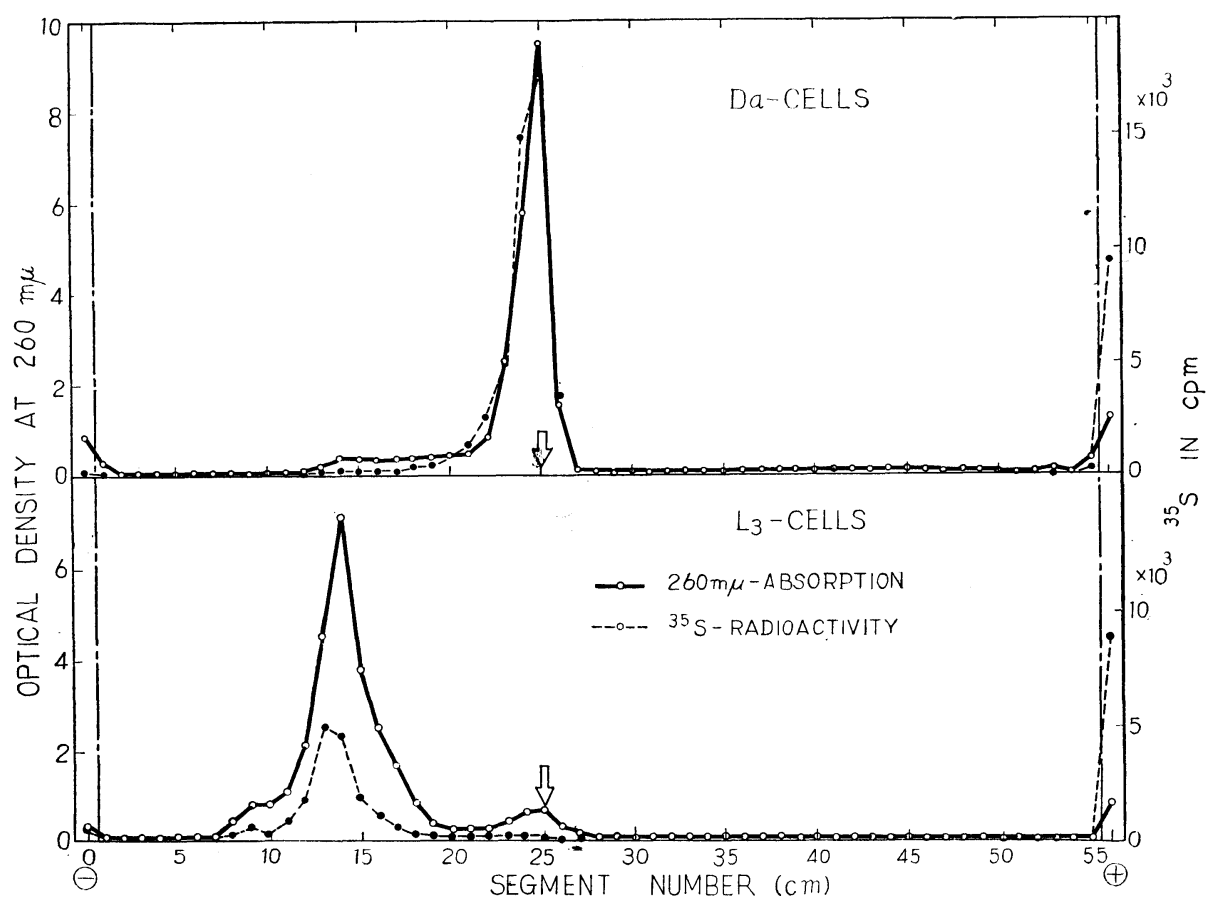

Fig. 1. Electrophoretic patterns of the cold TCA-extracts obtained from $\mathrm{D}_{\mathrm{a}}$ - and $\mathrm{L}_{3}$-cells. Medium: starch in acetate buffer of $\mathrm{pH} 3.6$ with an ionic strength of 0.1. A cell having two parallel troughs was used, each trough being $2 \times 1.5 \times 55 \mathrm{~cm}$ in size. Experiment lasted 38 hours at $3^{\circ}$, the average potential gradient being $5 \mathrm{v} / \mathrm{cm}$. The arrows show the place of application of the original sample. After the electrophoresis, the starch in the cell was cut into $1-\mathrm{cm}$ sections, and each of them was extracted with $5 \mathrm{ml}$ of distilled water. Segment numbers 0 and 56 represent the buffer reservoirs placed at both ends of the cell. The values given for these segments representwith reference to the values given for the other segments - the total quantities of sulfur and $260 \mathrm{~m} \mu$-absorbing substancs migrated into these reservoirs. 


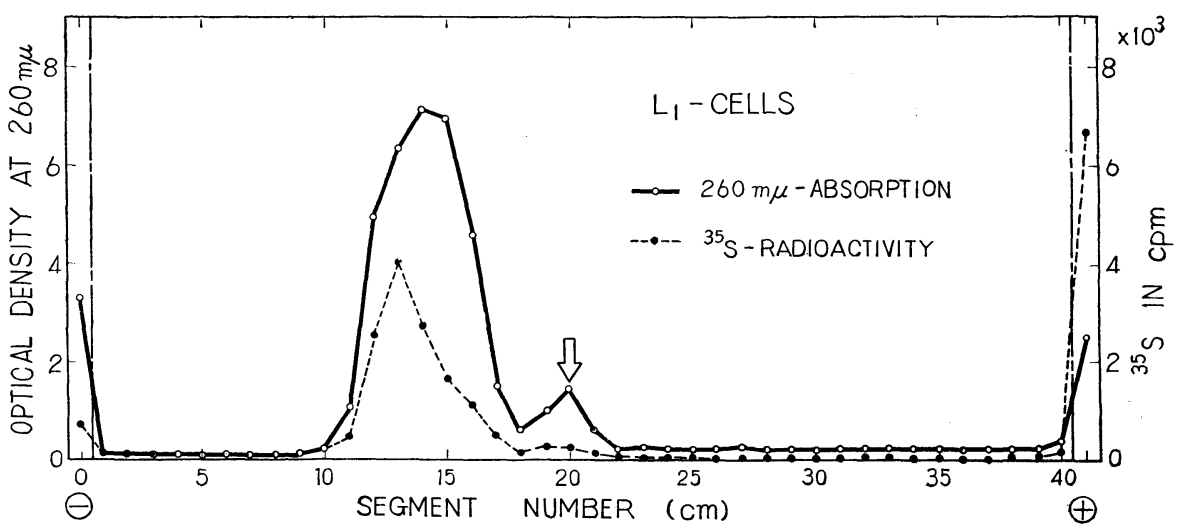

Fig. 2. An electrophoretic pattern of the cold TCA- extract obtained from $\mathrm{L}_{1^{-}}$ cells. The experimental conditions were the same as those described in Fig. 1, except that the cell having the dimension of $3 \times 1.5 \times 40 \mathrm{~cm}$ was used.

when incubated in the dark. During the transformation of $\mathrm{L}_{1^{-}}$to $\mathrm{L}_{3}$-cells, a considerable amount of nuclear substances (nucleic acids and proteins) is formed and the nuclear division takes place giving rise to a number (usually 4) of daughter-nuclei corresponding to the amount of DNA accumulated in the meantime.

In view of these facts it seemed worth while to investigate whether or not the properties of the S-containing peptide-nucleotide compound may be modified during the stage from $\mathrm{D}_{\mathrm{a}}$ - to $\mathrm{L}_{3}$-cells. It has already been demonstrated in our previous paper $(3)$ that, when the TCA-extract of $\mathrm{D}_{\mathrm{a}}$ -

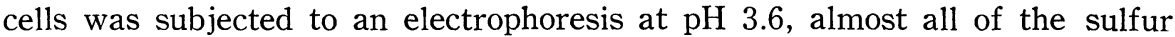
and u.v.-absorbing substances moved slightly toward the cathode forming ostensibly a single peak, while at $\mathrm{pH} 5.0$ the electrophoretic pattern was separated into a number of peaks and the majority of them moved toward the anode. Using the TCA-extract of $\mathrm{D}_{\mathrm{a}}$-cells as a control, the corresponding extracts obtained from $\mathrm{L}_{1}$ - and $\mathrm{L}_{3}$-cells were subjected to electrophoresis at $\mathrm{pH}$ 3.6. The results obtained are reproduced in Figs. 1 and 2. As may be seen, the compounds obtained from $\mathrm{L}_{1}$ - and $\mathrm{L}_{3}$-cells moved toward the cathode appreciably faster than that obtained from $D_{a}$-cells. However, the peak fractions obtained from these three samples showed apparently the same absorption spectra in the ultraviolet region (Fig. 3). As far as the preliminary paper-chromatographic experiments were concerned, the sulfur substances contained in the peak fractions obtained from these samples $\left(D_{a}\right.$, $\mathrm{L}_{1}$ and $\left.\mathrm{L}_{3}\right)$ also appeared identical with each other. These observations seem to suggest that the property of the S-containing peptide-nucleotide compound changes, if any, only slightly according to the stage of cell development.

(2) Electrophoretic pattern of the cold TCA-extract of S-deficient cells

It has already been reported that, when $D_{\mathrm{a}}$-cells were grown synchro- 
nously in a sulfur-free medium, the cell mass and nuclear substances (deoxypentose nucleic acid and pentose nucleic acid) could increase only to some extent, and that, although each nucleus eventually divided into two, there

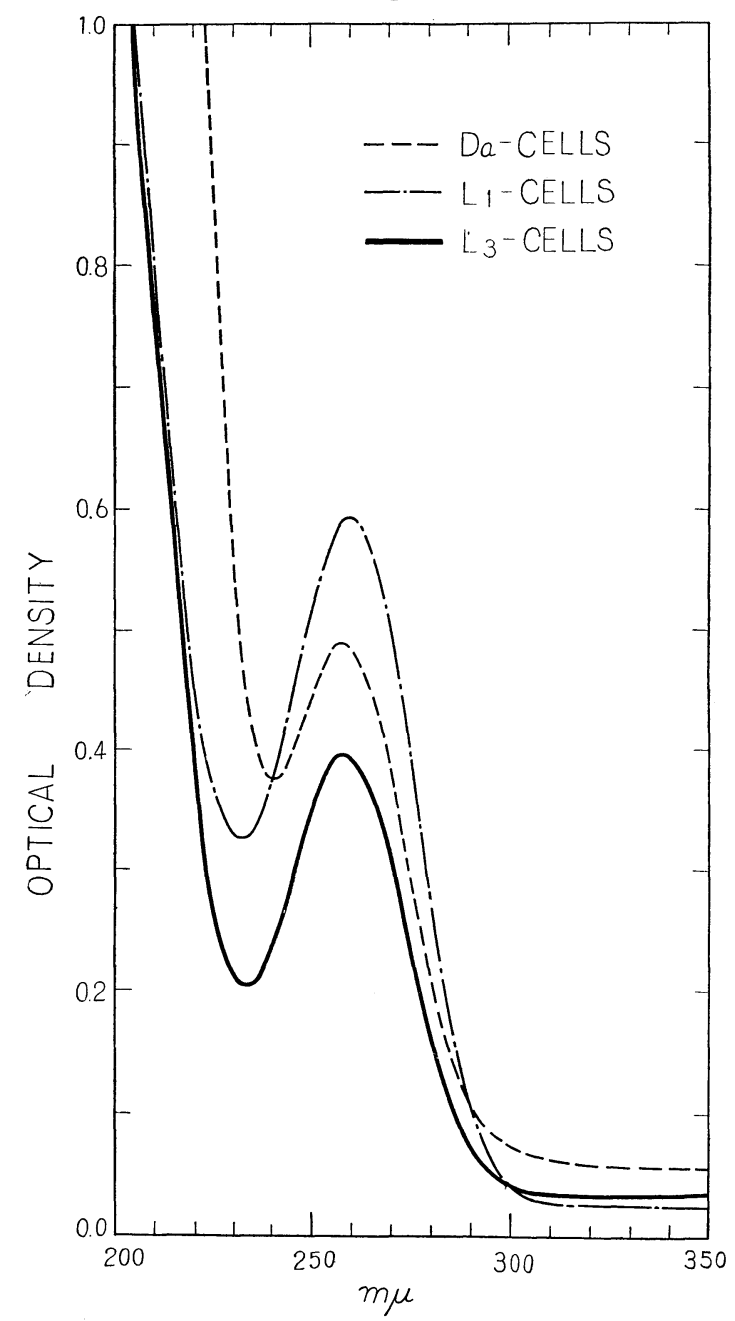

Fig. 3. Ultraviolet absorption spectra (at $\mathrm{pH}$ 5) of the peak fractions obtained by the zone electrophoresis of the cold TCA-extracts of $\mathrm{D}_{\mathrm{a}^{-}}, \mathrm{L}_{1^{-}}$and $\mathrm{L}_{3}$-cells. occurred no cellular division at all. In such S-starved cells most of the sulfur substances were found to be confined in the TCA-insoluble fraction. The cold TCAextract obtained from such S-starved cells, which had previously been labeled with ${ }^{35} \mathrm{~S}$, gave an electrophoretic pattern as shown in Fig. 4. As may be seen, an extremely small amount of sulfur could be detected in the extract, while a considerable amout of u.v.-absorbing substances were present. Also in this case, the u.v.-absorbing substances moved toward the cathode (a little faster than the substances obtained from $\mathrm{D}_{\mathrm{a}}$-cells), forming a single peak. As shown in Fig. 5 , the ultraviolet absorption spectrum of this peak fraction was also strikingly similar to that of the corresponding peak fraction obtained from $\mathrm{D}_{\mathrm{a}}$-cells. By the ninhydrin test of the samples it was revealed that, in the case of S-deficiency, the u.v.absorbing peak was not accompanied by peptides and amino acids, both of which had moved toward the cathode much faster than the u.v.-absorbing peak, a fact which is in sharp contrast to the observations made with the extract obtained from normal cells. These results may be taken as indicating that the peptide moiety originally present in the $D_{a}$-cells might have been transformed into insoluble (conceivably proteinous) substance(s) during the 


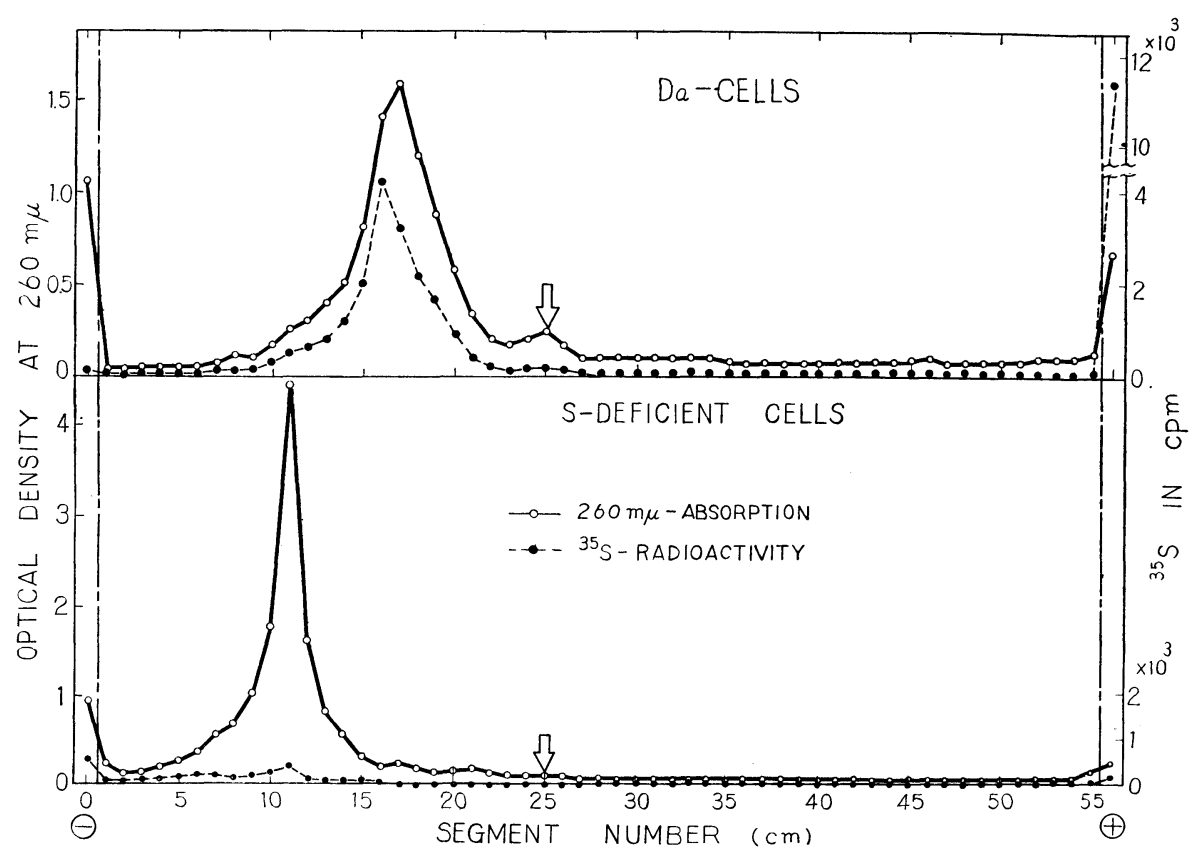

Fig. 4. Electrophoretic patterns of the cold TCA-extracts obtained from normal $\mathrm{D}_{\mathrm{a}}$-cells and the sulfur-deficient cells. The experimental conditions were the same as those described in Fig. 1.

period of S-starvation.

The experiment reproduced in Fig. 6 shows that during the period of S-starvation (starting from $\mathrm{D}_{\mathrm{a}}$-cells) the u.v.-absorbing compound(s) (in the cold PCA-extract) increased remarkably in quantity, indicating that the nucleotide-complex itself could be formed, at least to a certain degree, even under the condition of S-deficiency ${ }^{1}$. As mentioned above, however, the u.v.-absorbing substances formed in the S-starved cells, unlike the corresponding substances existing in normal cells, are not accompanied by the peptide moiety.

It has been observed ( 6 ) that in the S-starved cells the synthesis of nucleic acids could not proceed beyond a certain limit, and that $(7)$, when such cells were incubated (under non-photosynthesizing conditions) in a medium containing sulfate only, there occurred anew the formation of the sulfurcontaining peptide-nucleotide complex followed by the synthesis of nucleic acids, which led eventually to the process of cell division. These facts together with the observation that a peptide-free u.v.-absorbing substance(s) accumulates in S-starved cells may be interpreted as indicating that the S-containing peptide-nucleotide complex found in normal cells may be an intermediate in the synthesis of nucleic acids and probably of some proteins, and that the peptide- (and S-) free nucleotides found in S-starved cells may be

1 In the absence of $\mathrm{S}$, however, the final quantity of the u.v.-absorbing substance formed was far less than that formed in the presence of sulfur. 
a precursor or a remnant moiety of the former, which are incapable of being incorporated into nucleic acids owing to the absence of the peptide-moiety.

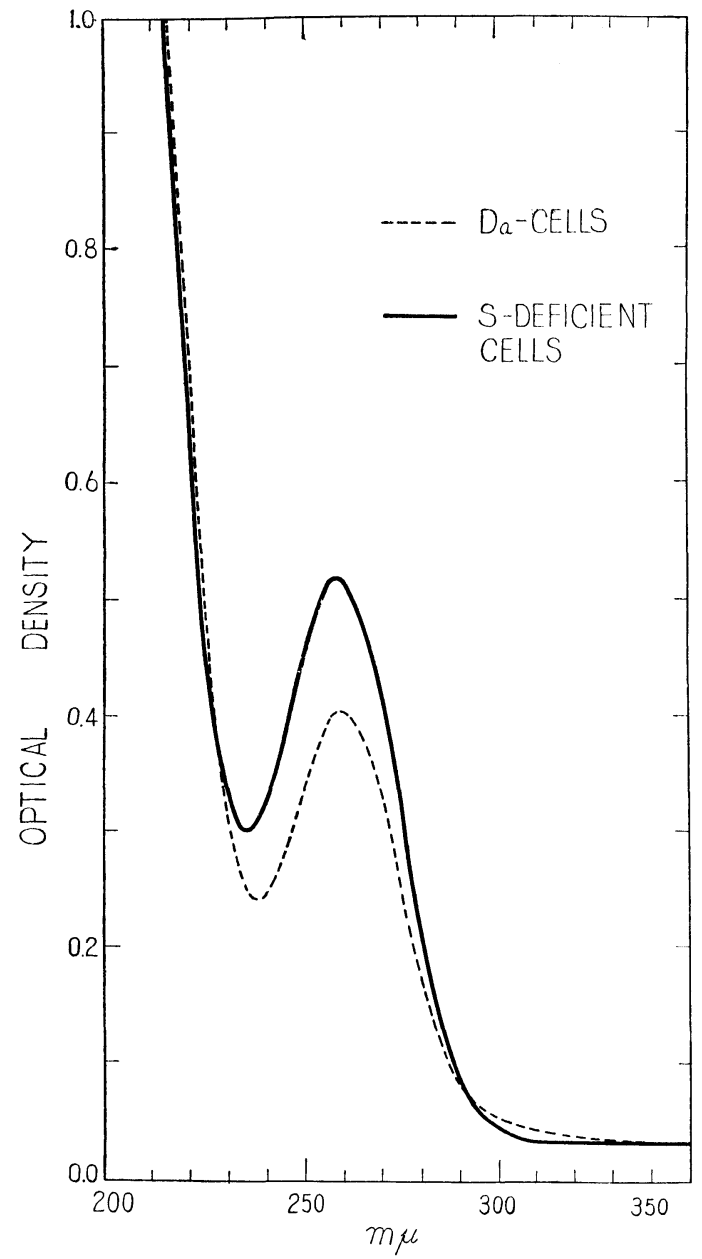

Fig. 5. Ultraviolet absorption spectra (at $\mathrm{pH}$ 5) of the peak fractions obtained by the zone electrophoresis of the cold TCA-extracts of $\mathrm{D}_{\mathrm{a}}$-cells and the sulfurdeficient cells.
These observations and reasonings seem to be in line with those reported recently by several other workers. Schmidt et al. (8) have observed that, in the yeast, S-starvation caused a halt of both protein- and ribonucleic acid-synthesis, while the formation of soluble nucleotides occurred unabated. It seems at present to be generally conceded $(9,10,11)$ that ribonucleic acid and proteins are formed from a pool of common precursors, i.e., amino acids bound to nucleotidic compound. It thus seems not presumptuous to assume that the role of the S-containing peptide-nucleotide complex in the metabolism of Chlorella cells may be to act as an intermediate in the syntheses of nucleic acids and possibly also of some essential proteins.

\section{SUMMARY}

(1) The sulfur-containing peptide-nucleotide compound(s), whose existence in the TCA-extract of Chlorella cells has been discovered previously, was separated from synchronously grown algal cells at different stages of their life cycle. As far as the electrophoretic experiments performed at $\mathrm{pH}$ 3.6 were concerned, the compound isolated at the stages of cellular ripening (stages of nuclear division) showed almost the same properties as that isolated from younger unripened cells.

(2) When the algal cells were grown in a sulfur-deficient medium, the 
TCA-extract prepared by the same procedure contained a nucleotide-complex, which, in the electrophoretic field, behaved almost in the same manner as the normal peptide-nucleotide complex, but, in sharp contrast to the latter, it contained neither sulfur nor the peptide-moiety.

(3) Based on these findings and on the other data thus far obtained, it was inferred that the S-containing peptide-nucleotide complex found in normal cells may be an intermediate in the syntheses of nucleic acids and probably of some proteins, and that the peptide-free nucleotides found in S-starved cells may be a precursor or a remnant moiety of the former, which are incapable of being utilized in the syntheses of nucleic acids owing to the absence of the peptidemoiety.

\section{ACKNOWLEDGEMENTS}

The expenses for this work

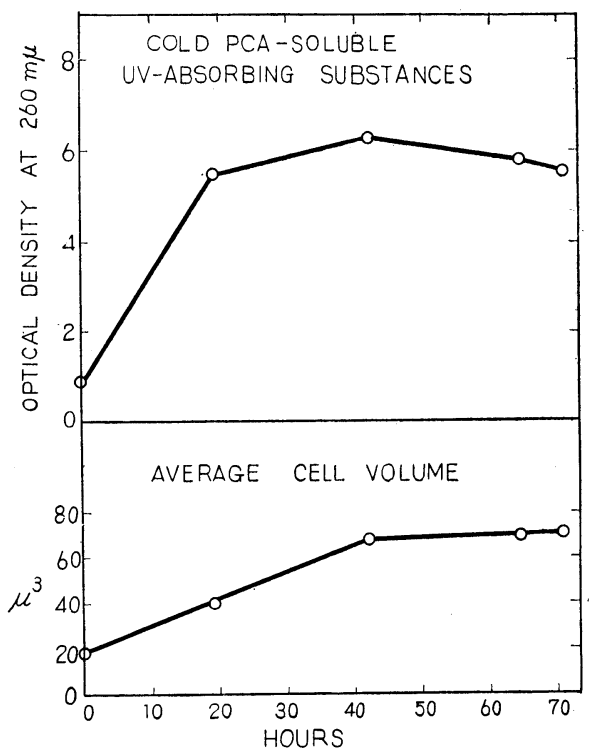

Fig. 6. Course of formation of the cold PCA-soluble u.v.-absorbing substances during the synchronous culture of Chlorella in a sulfur-free medium starting from the $D_{\mathrm{a}}$-cells. was defrayed from the grants from the Ministry of Education and the Rockefeller Foundation. To these bodies we extend our grateful thanks.

\section{REFERENCES}

(1) E. Hase, S. Mihara, H. Otsuka and H. Tamiya: Biochim. Biophys. Acta, 32, 298 (1959).

(2) E. Hase, S. Mihara and H. Otsuka: J. Gen. Appl. Microbiol., 5, 43 (1959).

(3) E. Hase, S. Mihara, H. Otsuka and H. Tamiya: Arch. Biochem. Biophys., 83, 170 (1959).

(4) E. Hase, H. Otsuka, S. Mihara and H. Tamiya: Biochim. Biophys. Acta, 35, 180 (1959).

(5) E. HaSe, Y. Morimura and H. Tamiya: Arch. Biochem. Biophys., 69, 149 (1957).

(6) E. HaSe, Y. Morimura, S. Mihara and H. TamiYa: Arch. Mikrobiol., 32, 87 (1958).

(7) E. Hase, S. Minara and H. Tamiya: Paper submitted to Plant and Cell Physiol.

(8) G. Schmidt, K. Seraidarian, L. M. Greenbaum, M. D. Hickey and S. J.

ThanNHAuSer: Biochim. Biophys. Acta, 20, 135 (1956).

(9) J. L. SIMKIN and T. S. WoRK: Nature, 179, 1214 (1957).

(10) H. Chantrenne: Ann. Rev. Biochem., 27, 35 (1958).

(11) J. L. Simkin: Ann. Rev. Biochem., 28, 145 (1959). 